\title{
Comment on "In Vivo [18 F]GE-179 Brain Signal Does Not Show NMDA-Specific Modulation with Drug Challenges in Rodents and Nonhuman Primates"
}

DOI:

10.1021/acschemneuro.8b00246

\section{Document Version \\ Accepted author manuscript}

Link to publication record in Manchester Research Explorer

Citation for published version (APA):

Mcginnity, C. J., Årstad, E., Beck, K., Brooks, D. J., Coles, J. P., Duncan, J. S., Galovic, M., Hinz, R., Hirani, E., Howes, O. D., Jones, P. A., Koepp, M. J., Luo, F., Riaño Barros, D. A., Singh, N., Trigg, W., \& Hammers, A. (2018). Comment on "In Vivo [18 F]GE-179 Brain Signal Does Not Show NMDA-Specific Modulation with Drug Challenges in Rodents and Nonhuman Primates". ACS Chemical Neuroscience. https://doi.org/10.1021/acschemneuro.8b00246

\section{Published in:}

ACS Chemical Neuroscience

\section{Citing this paper}

Please note that where the full-text provided on Manchester Research Explorer is the Author Accepted Manuscript or Proof version this may differ from the final Published version. If citing, it is advised that you check and use the publisher's definitive version.

\section{General rights}

Copyright and moral rights for the publications made accessible in the Research Explorer are retained by the authors and/or other copyright owners and it is a condition of accessing publications that users recognise and abide by the legal requirements associated with these rights.

\section{Takedown policy}

If you believe that this document breaches copyright please refer to the University of Manchester's Takedown Procedures [http://man.ac.uk/04Y6Bo] or contact uml.scholarlycommunications@manchester.ac.uk providing relevant details, so we can investigate your claim.

\section{OPEN ACCESS}


5 Authors

6 Colm J. McGinnity ${ }^{1} 2^{*}$, Erik Årstad ${ }^{3}$, Katherine Beck ${ }^{4}$, David J. Brooks ${ }^{5}$, Jonathan P. Coles ${ }^{6}$, John S.

7 Duncan $^{7}$, Marian Galovic ${ }^{7,8}$, Rainer Hinz ${ }^{9}$, Ella Hirani ${ }^{10}$, Oliver D. Howes ${ }^{4}$, Paul A. Jones ${ }^{10}$, Matthias J.

8 Koepp $^{7}$, Feng Luo ${ }^{10}$, Daniela A. Riaño Barros ${ }^{11}$, Nisha Singh ${ }^{1,12}$, William Trigg ${ }^{13}$, Alexander Hammers ${ }^{1,}$ 92.

\section{Affiliations}

${ }^{1}$ School of Biomedical Engineering and Imaging Sciences, King's College London, UK

${ }^{2}$ King's College London \& Guy's and St Thomas' PET Centre, St Thomas' Hospital, UK

${ }^{3}$ Organic Chemistry and Chemical Biology Section, Department of Chemistry, University College London, UK

${ }^{4}$ Department of Psychosis Studies, Institute of Psychiatry, Psychology and Neuroscience, King's College London, UK

$17{ }^{5}$ Department of Nuclear Medicine, Aarhus University, Denmark, and Institute of Neuroscience, Newcastle University, UK

${ }^{6}$ Division of Anaesthesia, Department of Medicine, University of Cambridge, UK

${ }^{7}$ Department of Clinical and Experimental Epilepsy, University College London Institute of Neurology, UK, and Epilepsy Society, UK 
${ }^{10} \mathrm{GE}$ Healthcare Ltd, UK

$25 \quad{ }^{11}$ South London and Maudsley NHS Foundation Trust, UK

$26{ }^{12}$ Department of Neuroimaging, Institute of Psychiatry, Psychology and Neuroscience, King's College

27 London, UK

$28{ }^{13}$ GE Healthcare Ltd, UK; current affiliation Adaptimmune Ltd, Abingdon, UK 


\section{Abstract}

Schoenberger and colleagues (2018; ACS Chem. Neurosci. 9, 298-305) recently reported attempts to demonstrate specific binding of the positron emission tomography (PET) radiotracer, $\left[{ }^{18} \mathrm{~F}\right] \mathrm{GE}-179$, to NMDA receptors in both rats and Rhesus macaques. GE-179 did not work as expected in animal models; however, we disagree with the authors' conclusion that "the $\left[{ }^{18} \mathrm{~F}\right] \mathrm{GE}-179$ signal seems to be largely nonspecific".

It is extremely challenging to demonstrate specific binding for the use-dependent NMDA receptor intrachannel ligands such as $\left[{ }^{18} \mathrm{~F}\right] \mathrm{GE}-179$ in animals via traditional blocking, due to its low availability of target sites $\left(B_{\max }^{\prime}\right)$. Schoenberger and colleagues anaesthetised rats and rhesus monkeys using isoflurane, which has an inhibitory effect on NMDA receptor function and thus would be expected to further reduce the $B_{\max }^{\prime}$.

The extent of glutamate release achieved in the provocation experiments is uncertain, as is whether a significant increase in NMDA receptor channel opening can be expected under anaesthesia.

Prior data suggest that the uptake of di-substituted arylguanidine-based ligands such as GE179 can be reduced by phencyclidine binding site antagonists, if injection is performed in the absence of ketamine and isoflurane anaesthesia, e.g. with GE-179's antecedent, CNS 5161 (Biegon et al., 2007), and with GMOM (van der Doef et al., 2016). However, the extent of non-specific uptake remains uncertain.

\section{Keywords}

$\left[{ }^{11} \mathrm{C}\right] \mathrm{CNS} 5161,\left[{ }^{18} \mathrm{~F}\right] \mathrm{GE}-179$, isoflurane, ketamine, NMDA, PET. 
51 Graphic for Table of Contents<smiles>CSc1cccc(N(C)C(=N)Nc2cc(SCC[18F])ccc2Cl)c1</smiles><smiles>CSc1ccc(Cl)c(NC(=N)N(C)c2cccc(OC[18F])c2)c1</smiles><smiles>CSc1cccc(N([14CH3])C(=N)Nc2cc(SC)ccc2Cl)c1</smiles><smiles>CN(C(=N)Nc1cccc2ccccc12)c1cccc([Al])c1</smiles>

52<smiles>COc1cccc(N(C)C(=N)Nc2cc(SC)ccc2Cl)c1</smiles> 
54

55

\section{Introduction}

Alterations in N-methyl D-aspartate (NMDA) receptor activation are implicated in the pathophysiology of several neuropsychiatric disorders, including epilepsy, schizophrenia and traumatic brain injury. Imaging NMDA receptor activation in vivo has proven challenging ${ }^{1} \cdot\left[{ }^{18} \mathrm{~F}\right] \mathrm{GE}-$ $179^{2}$ is a candidate positron emission tomography (PET) radiotracer for this purpose that has shown expected changes in both rat and human studies ${ }^{3-5}$. Schoenberger and colleagues recently reported attempts to demonstrate specific binding of $\left[{ }^{18} \mathrm{~F}\right] \mathrm{GE}-179$ to NMDA receptors in both rats and Rhesus macaques $^{6}$ in well-founded experiments simultaneously combining PET and magnetic resonance imaging (MRI). Although the experiments conducted provide solid evidence that GE-179 does not work as expected in animal models, we disagree with the authors' conclusion that "the $\left[{ }^{18} \mathrm{~F}\right] \mathrm{GE}-179$ signal seems to be largely nonspecific", for the reasons outlined below.

\section{The challenge of evaluating use-dependent PCP-site radiotracers}

Unlike most other neuroreceptor radiotracers, $\left[{ }^{18} \mathrm{~F}\right] \mathrm{GE}-179$ uptake is expected to reflect not only receptor distribution but also receptor "state", i.e. it should exhibit "use-dependency". The proportion of NMDA receptors that are in the open state at any one point of time in healthy rodents, macaques and humans is unknown and the estimates of the probability of channel opening vary considerably (e.g. $0.002^{6}-0.3^{7}$ ). We believe that it is extremely challenging to demonstrate specific binding for $\left[{ }^{18} \mathrm{~F}\right] \mathrm{GE}-179$ in animals via traditional blocking as in ${ }^{6}$, due to its low and inconstant availability of target sites $\left(B_{\max }^{\prime}\right)$.

\section{Effects of anaesthesia on PCP-site availability} guanidine $))^{2}$ is one of several putative di-substituted arylguanidine-based ligands with selectivity for the intrachannel phencyclidine (PCP) binding site of the NMDA receptor. Other molecules in this

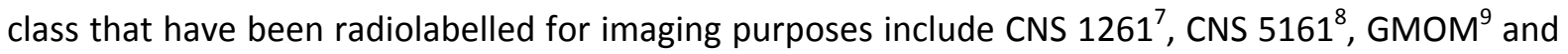


PK-209 ${ }^{10}$ (Figure 1). The PCP binding site only becomes available when the receptor is in the "open" state, i.e. on simultaneous binding of both the agonist glutamate and a co-agonist such as glycine, accompanied by cell depolarisation.

Blocking studies of putative PCP-site NMDA-selective radiotracers are confounded by the use of general anaesthesia. In reference ${ }^{6}$, the rats were anaesthetised via isoflurane inhalation, and the macaques were anaesthetised with ketamine and xylazene, with maintenance via isoflurane inhalation. The use of anaesthesia facilitates the acquisition of high-quality images. However, what is the effect of isoflurane, and the other anaesthetics used on $B_{\text {max }}^{\prime}$ ? Isoflurane and similar volatile anaesthetics have complex mechanisms of action which include a well-described inhibitory effect on NMDA receptor function ${ }^{11-25}$, and which is possibly mediated in part via competitive antagonism at the glutamate ${ }^{26}$ or glycine binding sites ${ }^{24,26-28}$. Such inhibition would be expected to reduce the already-low $B_{\max }^{\prime}$ of PCP-site radiotracers such as $\left[{ }^{18} \mathrm{~F}\right] \mathrm{GE}-179$. Demonstration of signal blockade in such circumstances would be extremely difficult.

\section{Effects of methamphetamine on PCP site availability}

In an attempt to increase $B_{\max }^{\prime}$ via provocation of NMDA receptor channel opening, Schoenberger and colleagues ${ }^{6}$ injected methamphetamine two minutes prior to injection of $\left[{ }^{18} \mathrm{~F}\right] \mathrm{GE}-179$ in rat studies and at 48 minutes p.i. in macaques studies, i.e. presumably administered after the induction of anaesthesia. Although single- dose methamphetamine may induce glutamate release ${ }^{29-30}$, there is some evidence that suggests the effect on glutamate release is negligible ${ }^{31-32}$. As the authors acknowledged, amphetamine and methamphetamine can actually directly inhibit the NMDA receptor $^{33-35}$. It is not clear whether significant glutamate release was actually achieved, and whether and when a significant increase in NMDA receptor channel opening can be expected under the competing influences of anaesthesia and perhaps methamphetamine. 
<smiles>CSc1cccc(N(C)C(=N)Nc2cc(SCC[18F])ccc2Cl)c1</smiles><smiles>CSc1cccc(N(C)C(=N)Nc2cc(SC)ccc2Cl)c1</smiles>

["C]CNS 5161<smiles>CSc1ccc(Cl)c(NC(=N)N(C)c2cccc(OC[18F])c2)c1</smiles><smiles>CN(C(=N)Nc1cccc2ccccc12)c1cccc(Br)c1</smiles>

[231]CNS 1261
102

Figure 1: NMDA receptor PET and SPECT (single photon emission tomography) putative PCP site radiotracers.

We interpret the experiments reported in reference ${ }^{6}$ in the context of the relevant studies for similar ligands (Figure 1). In short, partial blockade of radiotracer uptake has been achieved, and modest enhancement of the signal with challenge has been reported, as summarised below.

\section{Awake rats}

GE-179 is a derivative of CNS 5161 (N-[2-chloro-5-(2-methylsulfanyl)phenyl-]-N'-methyl-N'-(3methylsulfanylphenyl) guanidine); which has a low inhibition constant $\left(\mathrm{K}_{\mathrm{i}}\right)$ of $1.9 \pm 0.6 \mathrm{nM}$ versus MK$801^{36}$. In non-sedated rats, pre-treatment with cold MK-801 $(3 \mathrm{mg} / \mathrm{kg}$ intraperitoneal) reduced the 
cortex-to-cerebellum uptake ratio from 1.45 to 1.20 (i.e. 17\%), approximately, at 90 minutes postinjection of $\left[{ }^{3} \mathrm{H}\right] \mathrm{CNS} 5161^{37}$. Whilst complete activation of the NMDA channel is unlikely with pharmacological manipulation at doses that do not elicit seizures, pre-treatment with NMDA $40 \mathrm{mg} / \mathrm{kg}$ five minutes prior to injection of radiotracer increased the uptake ratio from 1.45 to 1.60 (i.e. $\sim 10 \%)$, approximately, with larger increases ( $31 \%)$ seen in the hippocampus. Approximately $17 \%$ blockade of signal has been seen in rats that were not sedated at the time of injection with ${ }^{123}$ I]CNS-1261 ${ }^{7}$.

Pre-treatment of a baboon with (cold) MK-801 (after induction of anaesthesia with ketamine and maintenance with isoflurane) did not significantly reduce $\left[{ }^{11} \mathrm{C}\right] \mathrm{GMOM}$ binding ${ }^{9}$, and similar to the results presented in reference ${ }^{6}$, a slight increase was actually observed. Crucially, however, pretreatment of awake rats with MK-801 (1 mg/kg intravenous) five minutes prior to injection produced a uniform decrease in binding of up to $28 \%{ }^{9}$. The discrepant findings between awake rats and anaesthetised baboons are consistent with an anaesthesia-induced reduction of $B_{\text {max }}^{\prime}$, in vivo. Pretreatment of the awake rats with the co-agonist D-serine produced increases in binding of up to $24 \%$, whereas the NR2B-selective antagonist Ro25-6981 produced decreases of up to $38 \%$. Blockade of the binding of a $\left[{ }^{18} \mathrm{~F}\right] \mathrm{PK}-209$, a $\left[{ }^{11} \mathrm{C}\right] \mathrm{GMOM}$ derivative, has also been seen with MK-801 pretreatment in awake rats ${ }^{10}$, and in Rhesus macaques that were anaesthetised using agents other than ketamine and isoflurane ${ }^{38}$.

A uniform decrease in $\left[{ }^{11} \mathrm{C}\right] \mathrm{GMOM}$ influx constant of approximately $66 \%$ was observed in six healthy, non-sedated human participants following early and prolonged administration of the low-affinity PCP-site antagonist, S-ketamine ${ }^{39}$. The decrease in radioactivity concentration $(\mathrm{kBq} / \mathrm{ml})$, as opposed to influx constant, was not quantified but appeared to be modest (see "Data Analysis section below) - opposed by a slight (7\%) increase in perfusion/extraction and accumulation in the non-specific compartment $\left(\mathrm{V}_{\mathrm{ND}} ; 10 \%\right)$. A reduction in volume-of-distribution $\left(\mathrm{V}_{\mathrm{T}}\right)$ of approximately $20 \%$ has also been observed with $\left[{ }^{123}\right.$ I]CNS- $1261^{40-41}$. 
In the rat experiments ${ }^{6}$, Schoenberger et al inferred the absence of an effect from the failure to observe 'a meaningful change in the whole-brain TAC'. Whilst in some experiments the displacement is so clear simple assessment of the whole-brain time-activity curve will suffice ${ }^{42}$, a more rigorous quantitative analysis of the data is usually required to establish the presence of an effect. Drug competition can cause changes of the bioavailability of the PET tracer due to changes of the peripheral metabolism, alterations of the delivery, binding to peripheral sites, etc. Therefore modelbased quantification of regional tracer binding in brain tissue is usually preferred over simpler methods when the expected effect sizes are in the order of a few per cent ${ }^{43}$. The possibility cannot be excluded that the authors missed small but measureable effects in their in vivo rat experiments because they did not calculate quantitative measures of regional $\left[{ }^{18} \mathrm{~F}\right] \mathrm{GE}-179$ binding.

\section{Discussion}

Taken together, these data suggest that the uptake/binding of di-substituted arylguanidine-based NMDA-selective radiotracers can be reduced by PCP site antagonists, if injection is performed in the absence of ketamine and isoflurane anaesthesia. We expect that this should be the case for $\left[{ }^{18} \mathrm{~F}\right] \mathrm{GE}-$ 179, particularly since it has already been reported for its antecedent $\left[{ }^{11} \mathrm{C}\right] \mathrm{CNS} 5161^{37}$. direct provocation of channel opening with the agonist $\mathrm{NMDA}^{37}$ and alternatively with the co-agonist D-serine ${ }^{9}$. Increased uptake/binding has also been demonstrated in conditions in which increased "endogenous" NMDA receptor channel opening is expected, such as deep brain stimulation ${ }^{44}$, dyskinesias ${ }^{45}$, epilepsy, ${ }^{5}$, and cerebral ischaemia ${ }^{46}$. There is good evidence, therefore, that these radiotracers specifically bind to the PCP site in vivo, and we suggest that the divergent findings in ${ }^{6}$ are explicable by the use of isoflurane and/or ketamine anaesthesia. A within-subject paired study design, in which $\left[{ }^{18} \mathrm{~F}\right] \mathrm{GE}-179$ is administered prior to anaesthesia for one scan and subsequent to anaesthesia in the other, would allow this hypothesis to be tested. If confirmed and if it proves 
valuable to perform pharmacological (or other) challenge before the induction of anaesthesia, this would advantage F-18 labelled agents such as $\left[{ }^{18} \mathrm{~F}\right] \mathrm{GE}-179$ over those limited by the short radioactive half-life of C-11 (e.g. $\left.\left[{ }^{11} \mathrm{C}\right] \mathrm{GMOM}\right)$.

The extent of blockade or alternatively the extent of enhancement that has been achieved thus far, in terms of change in radioactivity concentration, has been modest. The results presented in reference ${ }^{39}$ suggest that alterations in perfusion/extraction can confound the detection of blockade (and presumably enhancement). The modest alterations in signal might also have resulted in part from incomplete receptor blockade/enhancement; for example, Van der Doef and colleagues estimated that their ketamine dosing regimen (total $0.3 \mathrm{mg} / \mathrm{kg}$ over 135 minutes) resulted in an average occupancy of the PCP binding site of only approximately $19 \%^{39}$. Hence, it is not immediately apparent that non-specific binding should be particularly marked for GE-179, given its lipophilicity $\left(\log \mathrm{D}_{7.4}=2.5 \pm 0.1\right)$. However, the low volume of distribution observed for the second compartment $\left(V_{s}\right)$ of kinetic models is consistent with low specific binding in healthy specimens.

In conclusion, we believe that the experiments described in reference ${ }^{6}$, which contrast with those of several related studies ${ }^{9-10,37,39-41,47-48}$, do not adequately resolve the question of specific versus nonspecific binding for $\left[{ }^{18} \mathrm{~F}\right] \mathrm{GE}-179$ and similar radiotracers. Evaluation of NMDA receptorselective radiotracers is a challenging endeavour that will require continued experimental innovation. The data to date suggests that diarylguanidine-based PCP-site tracers are sensitive to channel opening in awake specimens, whereas the extent of non-specific uptake remains uncertain. $\left[{ }^{18} \mathrm{~F}\right] \mathrm{GE}-179$ and $\left[{ }^{11} \mathrm{C}\right] \mathrm{GMOM}$ might still find use in clinical populations in which marked alterations in channel opening probability are expected.

\section{Author Information}

*Corresponding author:

Colm J. McGinnity (CJM)

School of Biomedical Engineering and Imaging Sciences 
$4^{\text {th }}$ Floor Lambeth Wing

St Thomas' Hospital

190

Westminster Bridge Road

191

London, SE1 7EH

192

UK

193

Telephone: +44-(0)20 71889259

194

Fax: +44-(0)20 71883056

195

Email: colm.mcginnity@kcl.ac.uk

196

Author Contributions

197

All authors contributed to preparation of the manuscript.

198

199

200

201

202

203

204

205

206

207

208

209

210

211

212

213

\section{Funding Sources}

AH\&CJM, JPC, MG, MJK, and NS are currently supported by the Medical Research Council (UK; MR/N013042/1; MR/L013215/1 and MR/K02308X/1; MR/L013215/1; MR/L013215/1; and MR/K022733/1, respectively).

\section{Conflicts of Interest}

CJM, DARB, WT, DJB, JSD, MJK, and AH have conducted a study that used $\left[{ }^{18} \mathrm{~F}\right] \mathrm{GE}-179$ and was supported in part by GE Healthcare Ltd. EH, FL and JS are employees of GE Healthcare Ltd. EA and WT were employees of GE Healthcare Ltd. CJM, JSD, and MJK have received fees from GE Healthcare Ltd, but have never been employees of the organisation. JSD has also received fees from UCB Pharma, Eisai, and GSK. The remaining authors do not declare any conflicts of interest.

\section{References}

1. Waterhouse, R. N. (2003) Imaging the PCP site of the NMDA ion channel. Nucl. Med. Biol. 30, 869878.

2. Robins, E. G., Zhao, Y., Khan, I., Wilson, A., Luthra, S. K., and Årstad, E. (2010) Synthesis and in vitro evaluation of ${ }^{18} \mathrm{~F}$-labelled S-fluoroalkyl diarylguanidines: Novel high-affinity NMDA receptor antagonists for imaging with PET. Bioorg. Med. Chem. Lett. 20, 1749-1751. 
3. Lopez-Picon, F., Snellman, A., Shatillo, O., Lehtiniemi, P., Gronroos, T. J., Marjamaki, P., Trigg, W., Jones, P. A., Solin, O., Pitkanen, A., and Haaparanta-Solin, M. (2016) Ex Vivo Tracing of NMDA and GABA-A Receptors in Rat Brain After Traumatic Brain Injury Using ${ }^{18} \mathrm{~F}-\mathrm{GE}-179$ and ${ }^{18} \mathrm{~F}-\mathrm{GE}-194$ Autoradiography. J. Nucl. Med. 57, 1442-7.

4. McGinnity, C. J., Hammers, A., Riano Barros, D. A., Luthra, S. K., Jones, P. A., Trigg, W., Micallef, C., Symms, M. R., Brooks, D. J., Koepp, M. J., and Duncan, J. S. (2014) Initial evaluation of ${ }^{18} \mathrm{~F}-\mathrm{GE}-179$, a putative PET Tracer for activated N-methyl D-aspartate receptors. J. Nucl. Med. 55, 423-30.

5. McGinnity, C. J., Koepp, M. J., Hammers, A., Riano Barros, D. A., Pressler, R. M., Luthra, S., Jones, P. A., Trigg, W., Micallef, C., Symms, M. R., Brooks, D. J., and Duncan, J. S. (2015) NMDA receptor binding in focal epilepsies. J. Neurol. Neurosurg. Psychiatry 86, 1150-7.

6. Schoenberger, M., Schroeder, F. A., Placzek, M. S., Carter, R. L., Rosen, B. R., Hooker, J. M., and Sander, C. Y. (2018) In Vivo $\left[{ }^{18} \mathrm{~F}\right] \mathrm{GE}-179$ Brain Signal Does Not Show NMDA-Specific Modulation with Drug Challenges in Rodents and Nonhuman Primates. ACS Chem. Neurosci. 9, 298-305.

7. Owens, J., Tebbutt, A. A., McGregor, A. L., Kodama, K., Magar, S. S., Perlman, M. E., Robins, D. J., Durant, G. J., and McCulloch, J. (2000) Synthesis and binding characteristics of N-(1-naphthyl)-N'-(3$\left[{ }^{125} \mathrm{I}\right]$-iodophenyl)- $\mathrm{N}^{\prime}$-methylguanidine ([ $\left.\left.{ }^{125} \mathrm{I}\right]-\mathrm{CNS} 1261\right)$ : a potential SPECT agent for imaging NMDA receptor activation. Nucl. Med. Biol. 27, 557-564.

8. Zhao, Y., Robins, E., Turton, D., Brady, F., Luthra, S. K., and Årstad, E. (2006) Synthesis and characterization of N-(2-chloro-5-methylthiophenyl)- $\mathrm{N}^{\prime}$-(3-methylthiophenyl)- $\mathrm{N}^{\prime}$ -

$\left[{ }^{11} \mathrm{C}\right]$ methylguanidine $\left[{ }^{11} \mathrm{C}\right] \mathrm{CNS} 5161$, a candidate PET tracer for functional imaging of NMDA receptors. J. Labelled Comp. Radiopharm. 49, 163-170.

9. Waterhouse, R. N., Slifstein, M., Dumont, F., Zhao, J., Chang, R. C., Sudo, Y., Sultana, A., Balter, A., and Laruelle, M. (2004) In vivo evaluation of $\left[{ }^{11} \mathrm{C}\right] \mathrm{N}$-(2-chloro-5-thiomethylphenyl)- $\mathrm{N}^{\prime}$-(3-methoxyphenyl)- $\mathrm{N}^{\prime}$-methylguanidine $\left(\left[{ }^{11} \mathrm{C}\right] \mathrm{GMOM}\right)$ as a potential PET radiotracer for the PCP/NMDA receptor. Nucl. Med. Biol. 31, 939-948.

10. Klein, P. J., Schuit, R. C., Metaxas, A., Christiaans, J. A. M., Kooijman, E., Lammertsma, A. A., van Berckel, B. N. M., and Windhorst, A. D. (2017) Synthesis, radiolabeling and preclinical evaluation of a $\left[{ }^{11} \mathrm{C}\right] \mathrm{GMOM}$ derivative as PET radiotracer for the ion channel of the $\mathrm{N}$-methyl-D-aspartate receptor. Nucl. Med. Biol. 51, 25-32.

11. Yamakura, T., and Harris, R. A. (2000) Effects of gaseous anesthetics nitrous oxide and xenon on ligand-gated ion channels. Comparison with isoflurane and ethanol. Anesthesiology 93, 1095-101. 12. Yang, J., and Zorumski, C. F. (1991) Effects of isoflurane on N-methyl-D-aspartate gated ion channels in cultured rat hippocampal neurons. Ann. N. Y. Acad. Sci. 625, 287-9. 13. Solt, K., Eger, E. I., 2nd, and Raines, D. E. (2006) Differential modulation of human N-methyl-Daspartate receptors by structurally diverse general anesthetics. Anesth. Analg. 102, 1407-11. 14. Hollmann, M. W., Liu, H. T., Hoenemann, C. W., Liu, W. H., and Durieux, M. E. (2001) Modulation of NMDA receptor function by ketamine and magnesium. Part II: interactions with volatile anesthetics. Anesth. Analg. 92, 1182-91.

15. Ogata, J., Shiraishi, M., Namba, T., Smothers, C. T., Woodward, J. J., and Harris, R. A. (2006) Effects of anesthetics on mutant N-methyl-D-aspartate receptors expressed in Xenopus oocytes. J. Pharmacol. Exp. Ther. 318, 434-43.

16. Eger, E. I., 2nd, Liao, M., Laster, M. J., Won, A., Popovich, J., Raines, D. E., Solt, K., Dutton, R. C., Cobos, F. V., 2nd, and Sonner, J. M. (2006) Contrasting roles of the N-methyl-D-aspartate receptor in the production of immobilization by conventional and aromatic anesthetics. Anesth. Analg. 102, 1397-406.

17. Ranft, A., Kurz, J., Deuringer, M., Haseneder, R., Dodt, H. U., Zieglgansberger, W., Kochs, E., Eder, M., and Hapfelmeier, G. (2004) Isoflurane modulates glutamatergic and GABAergic neurotransmission in the amygdala. Eur. J. Neurosci. 20, 1276-80.

18. Ming, Z., Griffith, B. L., Breese, G. R., Mueller, R. A., and Criswell, H. E. (2002) Changes in the effect of isoflurane on $\mathrm{N}$-methyl-D-aspartic acid-gated currents in cultured cerebral cortical neurons with time in culture: evidence for subunit specificity. Anesthesiology 97, 856-67. 
19. Berg-Johnsen, J., and Langmoen, I. A. (1992) The effect of isoflurane on excitatory synaptic transmission in the rat hippocampus. Acta Anaesthesiol. Scand. 36, 350-5.

20. Bickler, P. E., Buck, L. T., and Hansen, B. M. (1994) Effects of isoflurane and hypothermia on glutamate receptor-mediated calcium influx in brain slices. Anesthesiology 81, 1461-9.

21. Zuo, Z., De Vente, J., and Johns, R. A. (1996) Halothane and isoflurane dose-dependently inhibit the cyclic GMP increase caused by N-methyl-D-aspartate in rat cerebellum: novel localization and quantitation by in vitro autoradiography. Neuroscience 74, 1069-75.

22. Nishikawa, K., and Maclver, M. B. (2000) Excitatory synaptic transmission mediated by NMDA receptors is more sensitive to isoflurane than are non-NMDA receptor-mediated responses.

Anesthesiology 92, 228-36.

23. Carla, V., and Moroni, F. (1992) General anaesthetics inhibit the responses induced by glutamate receptor agonists in the mouse cortex. Neurosci. Lett. 146, 21-4.

24. Martin, D. C., Abraham, J. E., Plagenhoef, M., and Aronstam, R. S. (1991) Volatile anesthetics and NMDA receptors. Enflurane inhibition of glutamate-stimulated $\left[{ }^{3} \mathrm{H}\right] \mathrm{MK}-801$ binding and reversal by glycine. Neurosci. Lett. 132, 73-6.

25. Harada, H., Kelly, P. J., Cole, D. J., Drummond, J. C., and Patel, P. M. (1999) Isoflurane reduces Nmethyl-D-aspartate toxicity in vivo in the rat cerebral cortex. Anesth. Analg. 89, 1442-7.

26. Martin, D. C., Plagenhoef, M., Abraham, J., Dennison, R. L., and Aronstam, R. S. (1995) Volatile anesthetics and glutamate activation of N-methyl-D-aspartate receptors. Biochem. Pharmacol. 49, 809-17.

27. Dickinson, R., Peterson, B. K., Banks, P., Simillis, C., Martin, J. C., Valenzuela, C. A., Maze, M., and Franks, N. P. (2007) Competitive inhibition at the glycine site of the N-methyl-D-aspartate receptor by the anesthetics xenon and isoflurane: evidence from molecular modeling and electrophysiology. Anesthesiology 107, 756-67.

28. Ishizaki, K., Yoshida, N., Yoon, D. M., Yoon, M. H., Sudoh, M., and Fujita, T. (1996) Intrathecally administered NMDA receptor antagonists reduce the MAC of isoflurane in rats. Can. J. Anaesth. 43, 724-30.

29. Stephans, S. E., and Yamamoto, B. K. (1994) Methamphetamine-induced neurotoxicity: roles for glutamate and dopamine efflux. Synapse 17, 203-9.

30. Ruda-Kucerova, J., Amchova, P., Havlickova, T., Jerabek, P., Babinska, Z., Kacer, P., Syslova, K., Sulcova, A., and Sustkova-Fiserova, M. (2015) Reward related neurotransmitter changes in a model of depression: An in vivo microdialysis study. World J. Biol. Psychiatry 16, 521-35.

31. Stephans, S. E., and Yamamoto, B. Y. (1995) Effect of repeated methamphetamine administrations on dopamine and glutamate efflux in rat prefrontal cortex. Brain Res. 700, 99-106. 32. Shoblock, J. R., Sullivan, E. B., Maisonneuve, I. M., and Glick, S. D. (2003) Neurochemical and behavioral differences between $d$-methamphetamine and $d$-amphetamine in rats.

Psychopharmacology (Berl.) 165, 359-69.

33. Yeh, G. C., Chen, J. C., Tsai, H. C., Wu, H. H., Lin, C. Y., Hsu, P. C., and Peng, Y. C. (2002) Amphetamine inhibits the $\mathrm{N}$-methyl-D-aspartate receptor-mediated responses by directly interacting with the receptor/channel complex. J Pharmacol. Exp. Ther. 300, 1008-16. 34. Lee, K. W., Kim, H. C., Lee, S. Y., and Jang, C. G. (2011) Methamphetamine-sensitized mice are accompanied by memory impairment and reduction of $\mathrm{N}$-methyl-d-aspartate receptor ligand binding in the prefrontal cortex and hippocampus. Neuroscience 178, 101-7.

35. Smith, K. J., Self, R. L., Butler, T. R., Mullins, M. M., Ghayoumi, L., Holley, R. C., Littleton, J. M., and Prendergast, M. A. (2007) Methamphetamine exposure antagonizes N-methyl-D-aspartate receptormediated neurotoxicity in organotypic hippocampal slice cultures. Brain Res. 1157, 74-80.

36. Hu, L. Y., Guo, J., Magar, S. S., Fischer, J. B., Burke-Howie, K. J., and Durant, G. J. (1997) Synthesis and pharmacological evaluation of $\mathrm{N}$-(2,5-disubstituted phenyl)-N'-(3-substituted phenyl)- $\mathrm{N}^{\prime}$ methylguanidines as N-methyl-D-aspartate receptor ion-channel blockers. J. Med. Chem. 40, 4281-9. 

characterization of $\left[{ }^{3} \mathrm{H}\right] \mathrm{CNS}-5161$--a use-dependent ligand for the N-methyl-D-aspartate receptor in rat brain. Synapse 61, 577-86. 38. Golla, S. S., Klein, P. J., Bakker, J., Schuit, R. C., Christiaans, J. A., van Geest, L., Kooijman, E. J., Oropeza-Seguias, G. M., Langermans, J. A., Leysen, J. E., Boellaard, R., Windhorst, A. D., van Berckel, B. N., and Metaxas, A. (2015) Preclinical evaluation of $\left[{ }^{18}\right.$ F]PK-209, a new PET ligand for imaging the ion-channel site of NMDA receptors. Nucl. Med. Biol. 42, 205-12. 39. van der Doef, T. F., Golla, S. S., Klein, P. J., Oropeza-Seguias, G. M., Schuit, R. C., Metaxas, A., Jobse, E., Schwarte, L. A., Windhorst, A. D., Lammertsma, A. A., van Berckel, B. N., and Boellaard, R. (2016) Quantification of the novel N-methyl-d-aspartate receptor ligand $\left[{ }^{11} \mathrm{C}\right] \mathrm{GMOM}$ in man. J. Cereb. Blood Flow Metab. 36, 1111-21.

40. Stone, J. M., Erlandsson, K., Arstad, E., Bressan, R. A., Squassante, L., Teneggi, V., Ell, P. J., and Pilowsky, L. S. (2006) Ketamine displaces the novel NMDA receptor SPET probe $\left[{ }^{123}\right.$ I]CNS-1261 in humans in vivo. Nucl. Med. Biol. 33, 239-43.

41. Stone, J. M., Erlandsson, K., Arstad, E., Squassante, L., Teneggi, V., Bressan, R. A., Krystal, J. H., Ell, P. J., and Pilowsky, L. S. (2008) Relationship between ketamine-induced psychotic symptoms and NMDA receptor occupancy: a [123I]CNS-1261 SPET study. Psychopharmacology (Berl.) 197, 401-8. 42. Malizia, A. L., Melichar, J. M., Brown, D. J., Gunn, R. N., Reynolds, A., Jones, T., and Nutt, D. J. (1997) Demonstration of clomipramine and venlafaxine occupation at serotonin reuptake sites in man in vivo. J. Psychopharmacol. 11, 279-281.

43. Lammertsma, A. A. (2017) Forward to the Past: The Case for Quantitative PET Imaging. J. Nucl. Med. 58, 1019-1024.

44. Vibholm, A., Christensen, J., Beniczky, S., Landau, A., Dietz, M., Moller, A., Christian Hedemann Sorensen, J., and Brooks, D. (2017) IN-VIVO IMAGING OF ACTIVATED NMDA RECEPTOR ION CHANNELS WITH THE RADIOLIGAND ${ }^{18} \mathrm{~F}-$ G179. Epilepsia 58 (Suppl. 5), S22.

45. Ahmed, I., Bose, S. K., Pavese, N., Ramlackhansingh, A., Turkheimer, F., Hotton, G., Hammers, A., and Brooks, D. J. (2011) Glutamate NMDA receptor dysregulation in Parkinson's disease with dyskinesias. Brain 134, 979-86.

46. Zhou, W., Bao, W., Jiang, D., Kong, Y., Hua, F., Lu, X., and Guan, Y. (2018) $\left[{ }^{18} \mathrm{~F}\right]-\mathrm{GE}-179$ positron emission tomography (PET) tracer for $N$-methyl- $D$-aspartate receptors: One-pot synthesis and preliminary micro-PET study in a rat model of MCAO. Nucl. Med. Biol. 61, 45-55.

47. Klein, P. J., Christiaans, J. A. M., Metaxas, A., Schuit, R. C., Lammertsma, A. A., van Berckel, B. N. M., and Windhorst, A. D. (2015) Synthesis, structure activity relationship, radiolabeling and preclinical evaluation of high affinity ligands for the ion channel of the $\mathrm{N}$-methyl-d-aspartate receptor as potential imaging probes for positron emission tomography. Bioorg. Med. Chem. 23, 1189-1206.

48. Knol, R. J., de Bruin, K., van Eck-Smit, B. L., Pimlott, S., Wyper, D. J., and Booij, J. (2009) In vivo $\left[{ }^{123}\right.$ I]CNS-1261 binding to D-serine-activated and MK801-blocked NMDA receptors: A storage phosphor imaging study in rats. Synapse 63, 557-64. 